\title{
Copepod feeding and reproduction in relation to phytoplankton development during the PeECE III mesocosm experiment
}

Copepod reproduction during

PeECE III

Y. Carotenuto et al.

Y. Carotenuto ${ }^{1}$, S. Putzeys ${ }^{2}$, P. Simonelli ${ }^{3}$, A. Paulino $^{3}$, M. Meyerhöfer $^{4}$, K. Suffrian ${ }^{4}$, A. Antia ${ }^{4}$, and J. C. Nejstgaard ${ }^{5}$

${ }^{1}$ Stazione Zoologica 'A. Dohrn', Naples, Italy

${ }^{2}$ Biological Oceanography Laboratory, Facultad de Ciencias del Mar, Universidad de Las Palmas de Gran Canaria, Las Palmas de Gran Canaria, Spain

${ }^{3}$ Department of Biology, University of Bergen, Bergen, Norway

${ }^{4}$ Leibniz Institut für Meereswissenschaften, IFM-GEOMAR, Kiel, Germany

${ }^{5}$ Department of Biology, UNIFOB, Bergen, Norway

Received: 17 October 2007 - Accepted: 17 October 2007 - Published: 25 October 2007 Correspondence to: Y. Carotenuto (ylenia@szn.it)

Title Page

Abstract Introduction

Conclusions

Tables References Figures

14 I

4

Back Close 


\section{Abstract}

Within the frame of the Pelagic Ecosystem $\mathrm{CO}_{2}$ Enrichment (PeECE III) experiment, reproduction and feeding of the copepod Calanus finmarchicus was monitored in relation to phytoplankton development in two mesocosms, at present $1 \times(350 \mu \mathrm{atm})$ and ca $3 \times$ 5 present $(1050 \mu \mathrm{atm}) \mathrm{CO}_{2}$ concentrations, respectively. Both mesocosms showed rapid phytoplankton growth after the initial nutrient additions and reached maximum chlorophyll (Chl) a concentrations around day 10. Flow-cytometry and specific pigment analysis (HPLC-CHEMTAX), showed that diatoms and prymnesiophyceae (Emiliania huxleyi (Ehux) and other nanoplankton) dominated the biomass. Feeding and egg production rates of $C$. finmarchicus developed similarly in both mesocosms, and were positively correlated with Chla, Ehux, diatom and prymnesiophyceae concentrations. Although the total number of copepod nauplii recruited during the experiment was similar in $1 x$ and $3 x$, significantly less nauplii were recruited in $3 x$ during the peak of the bloom compared to in $1 \times$. We conclude that the algae responsible for the higher biomass in $153 \times$ during the peak of the bloom (diatoms and Ehux), may have been relatively inferior food for $C$. finmarchicus naupliar recruitment, possibly due to a high $\mathrm{C}: \mathrm{N}$ ratio $(>8)$. Nevertheless, the 3 fold increase in $\mathrm{CO}_{2}$ concentration did not show any clear overall effect on bulk phytoplankton or zooplankton development over the whole experiment, suggesting a more complex coupling between increased $\mathrm{CO}_{2}$ and the nutritional status of the system.

\section{Introduction}

In the past centuries there has been an exponential increase of atmospheric $\mathrm{CO}_{2}$ concentration due to anthropogenic activity. In particular, carbon cycle models predicted that, by the end of this century, atmospheric $\mathrm{CO}_{2}$ concentration would rise from the actual $350 \mu \mathrm{atm}$ to $700 \mu \mathrm{atm}$ (IS92a scenario) or $970 \mu \mathrm{atm}$ of $\mathrm{CO}_{2}$ (A1FI scenario), depending on the consumption of fossil fuels (Houghton et al., 2001). If uncertainties
BGD

4, 3913-3936, 2007

Copepod

reproduction during

PeECE III

Y. Carotenuto et al.

Title Page

Abstract

Introduction

Conclusions

Tables

References

Figures

14

- I

4

Back

Close

Full Screen / Esc

Printer-friendly Version

Interactive Discussion 
about the magnitude of the climate feedback from the terrestrial biosphere are taken into account, such values could be even higher (up to $1260 \mu \mathrm{atm}$ ).

The rising of atmospheric $\mathrm{CO}_{2}$ could greatly impact the ocean food webs and the global carbon cycle, altering the buffering capacity $(\mathrm{pH})$ and the carbonate chemistry 5 of seawater (with important consequences for organisms with calcareous skeletons as coccolithophorids, corals and molluscs), and changing the strength of the biological pump that drives the carbon export from upper to deep oceans via carbon fixation by photosynthetic organisms.

Phytoplankton species differ in their efficiencies and regulation of carbon acquisition, 10 which translates in differences in carbon fixation rates and carbon-specific growth rates (Rost et al., 2003). The coccolithophorid Emiliania huxleyi, for example, has photosynthetic carbon fixation rates far from $\mathrm{CO}_{2}$ saturation at present $\mathrm{CO}_{2}$ levels and mainly relies on dissolved $\mathrm{CO}_{2}$ concentration for photosynthesis. Consequently $E$. huxleyi, might benefit from an increase in the surface ocean $\mathrm{CO}_{2}$ concentration compared to

other species, like for example diatoms, with carbon fixation rates close to $\mathrm{CO}_{2}$ saturation. Changes of surface ocean $\mathrm{CO}_{2}$ content, therefore, might affect phytoplankton species distribution and succession, and thereby secondary production of higher trophic level as herbivorous consumers. In the marine system, copepods represent the most abundant zooplankton consumers of algae and microzooplankton, playing a central role in carbon fluxes and elemental recycling. Copepod recruitment and population growth, are strongly related to phytoplankton and microzooplankton biomass and diversity via regulation of feeding, reproduction, growth and mortality rates. In addition, copepod feeding on calcifying organisms may also have implications for carbonate dissolution, especially during pre- or post-bloom situations, when grazing pressure can contribute to $14 \%$ of calcite standing stock dissolved in guts of copepods (Jansen and Wolf-Gladrow, 2001).

Manipulative experiments carried out in large outdoors enclosures (mesocosms) are an important tool to better understand the response of marine systems to an increasing $\mathrm{CO}_{2}$ level. Mesocosms represent a semi-natural approach that allows integrative as-
BGD

4, 3913-3936, 2007

\section{Copepod \\ reproduction during \\ PeECE III}

Y. Carotenuto et al.

Title Page

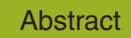

Introduction

Conclusions

Tables

References

Figures

14

$\rightarrow$

4

Back

Close

Full Screen / Esc

Printer-friendly Version

Interactive Discussion 
sessment of ocean physics, chemistry, primary and secondary production, as well as the study of their feedback effects on carbon cycle and global climate. In this respect, the Pelagic Ecosystem $\mathrm{CO}_{2}$ Enrichment study (PeECE III) was conducted in May 2005, with the general goal to investigate the response of a marine planktonic system to in5 creasing $\mathrm{CO}_{2}$ levels (Schulz et al., $2007^{1}$ ). Within the frame of the PeECE III study, our goal was to quantify the effects of increased $\mathrm{CO}_{2}$ concentrations on the feeding and secondary production of the key North Atlantic copepod Calanus finmarchicus in relation to the phytoplankton bloom development, in order to better understand the response of zooplankton to ocean acidification.

\section{Methods}

\subsection{Mesocosms used in this study}

A Pelagic Ecosystem $\mathrm{CO}_{2}$ Enrichment (PeECE III) experiment was carried out under semi-natural conditions at the Bergen Large Scale Mesocosm Facilities (Bergen, Norway) from 16 (experimental day 1) May to 10 June 2005 (Schulz et al., 2007 ${ }^{1}$ ). In order to span the full range of mesocosm $\mathrm{CO}_{2}$ treatments we used water from one of the mesocosms with present ( $375 \mu \mathrm{atm}) \mathrm{CO}_{2}$ concentration (M8) and one with ca three times $(3 \mathrm{x})$ increased $(1150 \mu \mathrm{atm}) \mathrm{CO}_{2}$ concentration (M2), respectively.

\footnotetext{
${ }^{1}$ Schulz, K. G., Riebesell, U., Bellerby, R. G. J., Biswas, H., Meyerhöfer, M., Müller, M. N., Egge, J. K., Nejstgaard, J. C., Neill, C., Wohlers, J., and Zöllner, E.: Build-up and decline of organic matter during PeECE III, Biogeosciences Discuss., in preparation, 2007.
}

BGD

4, 3913-3936, 2007

\section{Copepod}

reproduction during

PeECE III

Y. Carotenuto et al.

Title Page

Abstract

Introduction

Conclusions

References

Tables

Figures

14

$\rightarrow$

4

Back

Close

Printer-friendly Version

Interactive Discussion 


\subsubsection{Chlorophyll a and accessory pigments}

For the analysis of phytoplankton pigments 250 to $500 \mathrm{ml}$ water samples were filtered through $25 \mathrm{~mm}$ Whatman GF/F filters. The filters were frozen at $-20^{\circ} \mathrm{C}$ until analysis.

$5 \quad$ For pigment extraction filters were homogenised in plastic vials $(11 \mathrm{ml})$ together with $1 \mathrm{ml}$ acetone (100\%) and a mixture of glass beads ( 2 and $4 \mathrm{~mm}$ ) by shaking ( $5 \mathrm{~min}$ ) in a cooled Vibrogen cell mill (Buehler, Germany). Afterwards the extracts were centrifuged (5000 rpm, $10 \mathrm{~min}$, cooled at $\left.-10^{\circ} \mathrm{C}\right)$. The entire extraction process was executed under dimmed light to prevent photooxidation of the pigments.

10 Concentrations of pigments (chlorophyll and carotenoids) were determined by means of rp-HPLC (reverse-phase high-performance liquid chromatography), using the method of Barlow et al. (1997). Identification of pigments was carried out by comparing their retention times and absorption spectra obtained with a diode array spectrophotometer (WATERS) with those of pigment standards. Calibration was carried out with commercially available standards. Chlorophylla (Chla) was purchased from SIGMA, the other pigments from the International Agency for ${ }^{14} \mathrm{C}$ Determination, Denmark. Calculation of the composition of the phytoplankton communities was executed using the CHEMTAX program (Mackey et al., 1996), converting the concentrations of marker pigments to equivalents of Chla with suitable pigment to Chla ratios.

\subsubsection{Flow cytometer cell counts}

Autotrophic pico- and nanoeukaryotes and cyanobacteria were determined by Flow CytoMeter (FCM). All FCM analyses were performed with a FACSCalibur flow cytometer (Becton Dickinson) equipped with an air-cooled laser providing $15 \mathrm{~mW}$ at $488 \mathrm{~nm}$, and with standard filter set-up. The counts were obtained from fresh samples at high flow rate (average $104 \mu \mathrm{lmin}^{-1}$ ). The trigger was set on red fluorescence and the samples were analysed on the FCM for $300 \mathrm{~s}$. The FCM instrumentation and the remaining
BGD

4, 3913-3936, 2007

\section{Copepod \\ reproduction during \\ PeECE III}

Y. Carotenuto et al.

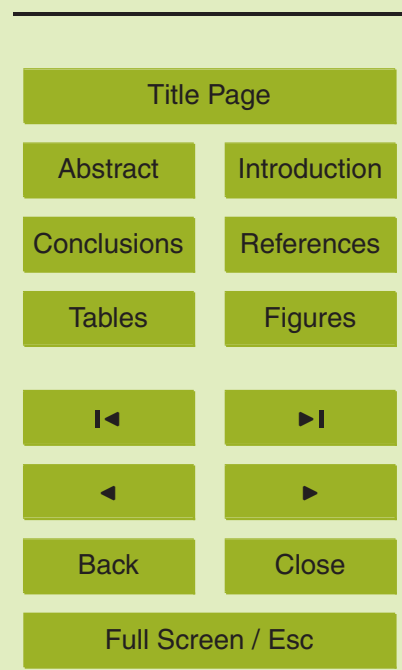

Printer-friendly Version

Interactive Discussion 
methodology followed the recommendations of Marie et al. (1999) and are described in more detail, for a similar study, by Larsen et al. (2001).

BGD

\subsection{Zooplankton}

Zooplankton samples were collected with an oblique WP3 $(300 \mu \mathrm{m})$ tow between 20$50 \mathrm{~m}$ depth at the Espegrend Biological Station, in the nearby Raunefjorden, and transferred within two hours to the laboratory at the University of Bergen (HIB). Ripe females of Calanus finmarchicus $(\mathrm{N}=60)$ were sorted at in situ temperature $\left(10^{\circ} \mathrm{C}\right)$ with a wide-mouth pipette under a dissecting microscope and placed individually in a 400-ml cylinder with a $500 \mu \mathrm{m}$ bottom net to prevent egg cannibalism. The cylinders were kept

10 in $500 \mathrm{ml}$ polyethylene beakers. Copepods were kept at approximately in situ temperature $\left(10^{\circ} \mathrm{C}\right.$, c.f. Schulz et al., $\left.2007^{1}\right)$ and dim light (16L:8D) during the entire experiment. They were incubated in natural surface water for $24 \mathrm{~h}$ before they were exposed to water from the mesocosms. At the start of the mesocosm experiment (Day 0), females were divided into two sub-groups $(\mathrm{N}=30)$, each group receiving water collected from M2 and M8, respectively. After each 24-h incubation period, the cylinders with the females were transferred to new beakers with freshly collected mesocosm water. Water samples were collected from the top mixed layers of each mesocosm using $25 \mathrm{~L}$ polycarbonate containers covered with a $200-\mu \mathrm{m}$ mesh (to exclude mesozooplankton), and dispatched within two hours to respective sub-groups of females.

20 Eggs and faecal pellets produced were collected by carefully pouring the content of each beaker onto a submerged $40-\mu \mathrm{m}$ filter and then back washing the filter into a 6 wells tissue plate. Eggs and pellets were immediately counted in the cold room under a dissecting microscope and re-incubated for $48 \mathrm{~h}$ to allow the eggs to hatch. Samples were then fixed with $4 \%$ buffered formaldehyde and the number of hatched nauplii was counted in order to calculate the percentage of hatching success. Reproduction of C. finmarchicus was monitored for 21 days, in order to calculate egg and faecal pellet production rates, percentage of hatching success and recruitment rate on the overall experiment.
4, 3913-3936, 2007

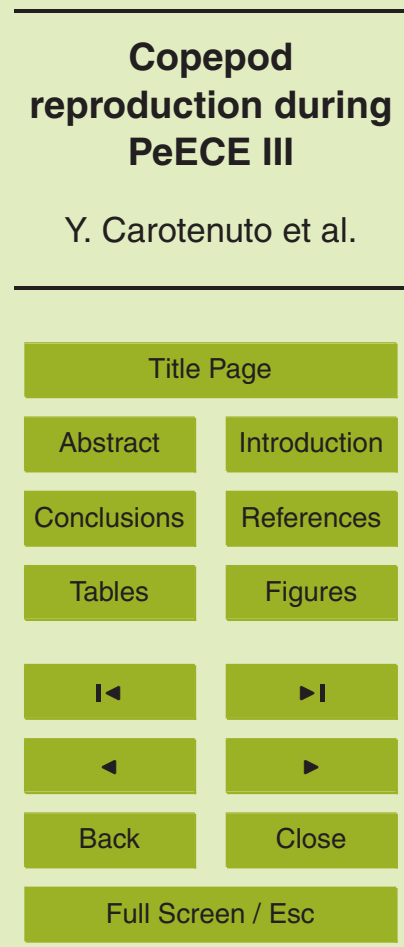

Printer-friendly Version

Interactive Discussion 
In addition, the daily faecal volume produced by $C$. finmarchicus females was monitored in both treatments on selected days, representative of pre-bloom (days 0,1 ), bloom (days 7, 9, 10,11) and post-bloom (days 13, 16, 17, 19, and 20) phases of the experiment. These values were used to calculate the corresponding copepod ingestion 5 rates using a linear relationship given by Nejstgaard et al. (2001a) for $C$. finmarchicus. The equation is

$Y=3.9 \times 10^{-7} \cdot X+1.9 \times 10^{-6}$

Where $Y$ is the daily carbon ingestion rate per female $\left(\mu \mathrm{g} \mathrm{C}^{-1} \mathrm{~d}^{-1}\right)$, and $X$ is the daily total faecal volume produced per female $\left(\mu \mathrm{m}^{3} \mathrm{Cf}^{-1} \mathrm{~d}^{-1}\right)$.

\subsection{Statistical analysis}

Student's t-test and Pearson correlation analysis were performed using the GraphPad Prism version 4 for Windows.

\section{Results}

3.1 Nutrient uptake and organic material build-up in the mesocosms

15 A detailed description of physical and chemical characteristics, including inorganic nutrient uptake and organic material build-up in the mesocosms are reported in Schulz et al. (2007) $)^{1}$. Briefly summarized, following addition of nitrate, phosphate and silicate, phytoplankton growth and organic material gradually built up in all mesocosms, while the inorganic silicate, phosphate and nitrate were depleted on experimental days 7,10 and 13, respectively, in all mesocosms (Schulz et al., 2007 ${ }^{1}$ ).

\section{BGD}

4, 3913-3936, 2007

\section{Copepod}

reproduction during

PeECE III

Y. Carotenuto et al.

Title Page

Abstract

Introduction

Conclusions

References

Tables

Figures

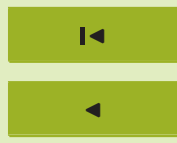

$\rightarrow 1$

Back

Close 


\subsubsection{HPLC pigments}

Chla, used as an index of total phytoplankton biomass, increased rapidly from day 0 to day $9-10$, when the highest values were measured $\left(10.5 \mu \mathrm{gl}^{-1}\right.$ and $12.6 \mu \mathrm{gl}^{-1}$ in M8

5 and M2, respectively). Chla declined rapidly afterwards, and remained low from day 16 onward (Fig. 1). Even though the pattern of bloom development was very similar in both mesocosms, significantly more Chla developed in the high $\mathrm{CO}_{2}$ mesocosm (M2) compared to M8 (paired t-test, $\mathrm{t}_{15}=4.61, p<0.001$ ), probably due to the slightly higher values observed from the peak of the bloom to the end of the experiment in M2.

10 Pigments based chemotaxonomy showed dominant contributions of diatoms and prymnesiophyceae (mainly Emiliania huxleyi) to total Chla (Fig. 1), with up to $5.6 \mu \mathrm{g} \mathrm{I}^{-1}$ in both mesocosms. There was no significant difference between the two mesocosms. Minor contributions stemmed from prasinophytes, dinoflagellates and cyanobacteria during the phytoplankton bloom in both mesocosms, although they slightly increased toward the end of the experiment.

\subsubsection{Flow cytometry cell counts}

Flow cytometry analysis revealed five distinct algal group signatures during the experiment, in either mesocosms: the Prymnesiophyceae Emiliania huxleyi (Ehux), Nanoplankton1 (Nano1), which included the Prymnesiophyceae Phaeocystis pouchetii solitary flagellate forms, Nanoplankton2 (Nano2), which included the Prymnesiophyceae Crysochromulina sp., Picoplankton (Pico), which included the Prasinophyceae Micromonas pusilla, and cyanobacteria, which mainly included Synechococcus sp. (Syn).

Cell densities of Ehux and Nano2 in either mesocosms increased from nearly zero 25 initial values to the highest abundance on day $7\left(\sim 5 \times 10^{3}\right.$ cells $\mathrm{ml}^{-1}$ and $\sim 1.5 \times 10^{3}$ cells $\mathrm{ml}^{-1}$ for Ehux and Nano2, respectively), although the Ehux bloom lasted significantly

Copepod reproduction during PeECE III

Y. Carotenuto et al.

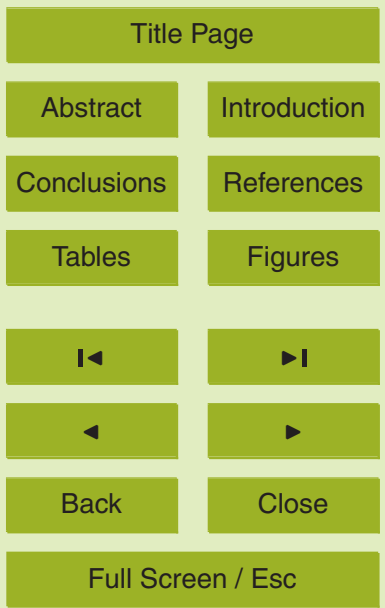

Printer-friendly Version

Interactive Discussion 
longer in the $3 \times \mathrm{CO}_{2}$ bag (M2) (Fig. 2a and b). The average abundance of Nano1 over the experiment was significantly lower and more stable in the present (M8) than in the $3 \times \mathrm{CO}_{2}$ bag (M2) $\left(3.1 \times 10^{3}\right.$ cells $\mathrm{ml}^{-1}$ and $4.9 \times 10^{3}$ cells $\mathrm{ml}^{-1}$, respectively), where up to $\sim 1 \times 10^{4}$ cells $\mathrm{ml}^{-1}$ were observed at the peak and the end of the bloom 5 (Fig. 2c). Temporal dynamic of Pico and Syn cell abundances were similar in both mesocosms and showed maximum values at the end of the bloom $\left(>6 \times 10^{4}\right.$ cells ml $^{-1}$ and $>1.2 \times 10^{5}$ cells $\mathrm{ml}^{-1}$, respectively), with slightly higher values measured for the $3 \times$ $\mathrm{CO}_{2}$ bag. A very high density was measured for Pico at the onset of the experiment $\left(>1.7 \times 10^{5}\right.$ cells $\left.\mathrm{ml}^{-1}\right)$ (Fig. $2 \mathrm{~d}$ and e).

\subsection{Zooplankton}

\subsubsection{Egg production and naupliar recruitment}

Temporal patterns of egg production rates of Calanus finmarchicus during the experiment were very consistent between the two mesocosm treatments (Fig. 3a). Initial fecundities (Day 0) were slightly different, with 8 eggs per female ${ }^{-1}$ per day $^{-1}$ (eggs $15 \mathrm{f}^{-1} \mathrm{~d}^{-1}$ ) in $\mathrm{M} 8$ and 20 eggs $\mathrm{f}^{-1} \mathrm{~d}^{-1}$ in $\mathrm{M} 2$, but then egg production increased similarly, reaching the highest value on day 9-10 (107 eggs $f^{-1} d^{-1}$ in M8 and 89 eggs $f^{-1} d^{-1}$ in M2). Fecundity decreased afterwards in both treatments to a minimum of 20 eggs $^{-1}$ $\mathrm{d}^{-1}$ in $\mathrm{M} 8$ and 24 eggs $\mathrm{f}^{-1} \mathrm{~d}^{-1}$ in $\mathrm{M} 2$, and remained low until the end of the experiment. The two egg production trends were not significantly different (paired t-test, $t_{20}=1.03$,

$20 \quad p>0.05)$. C. finmarchicus females of both treatments also produced, on average, the same daily number of eggs during their individual life span (46.2 eggs $\mathrm{f}^{-1} \mathrm{~d}^{-1}$ in the M8 treatment and 46.8 eggs $\mathrm{f}^{-1} \mathrm{~d}^{-1}$ in the $\mathrm{M} 2$ treatment, respectively).

In contrast to egg production rates, patterns of hatching success were less consistent between the two treatments, although initial values on day 0 were similarly low in both 25 mesocosms (47\% and 35\%, respectively) (Fig. 3b). Hatching success of females of both mesocosms increased similarly from day 0 to the highest value on day $4(85 \%$ and $74 \%$, in $M 8$ and $M 2$, respectively). Hatching decreased to less than $50 \%$ of viable

BGD

4, 3913-3936, 2007

\section{Copepod \\ reproduction during \\ PeECE III}

Y. Carotenuto et al.

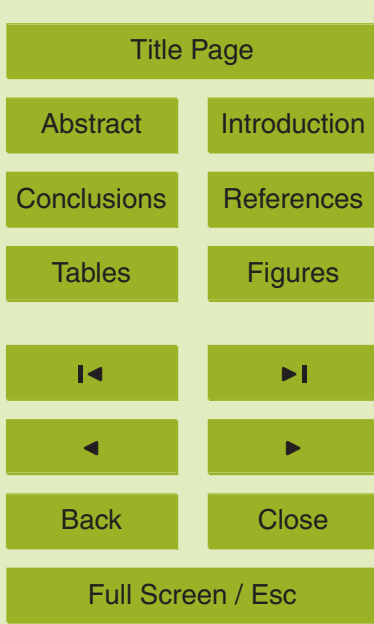

Printer-friendly Version

Interactive Discussion 
eggs on day 9 and 12 in the M8 and M2 mesocosm, respectively, and was followed by days of moderately high egg viability $(\geq 60 \%)$ in the final part of the experiment. These two trends were significantly different, either in term of temporal pattern (paired t-test, $\mathrm{t}_{20}=2.25, p<0.05$ ), or in term of average daily hatching success during the individual

5 life span of each female $\left(58.7 \%\right.$ and $49.1 \%$, respectively. Unpaired $t$-test, $t_{56}=2.15$, $p<0.05)$.

Temporal patterns of naupliar recruitment rates (nauplii $\mathrm{f}^{-1} \mathrm{~d}^{-1}$ ) where somehow similar in M2 and M8 (paired t-test, $t_{20}=1.08, p>0.05$ ), increasing from about 10 nauplii $\mathrm{f}^{-1} \mathrm{~d}^{-1}$ on day 0 , to 64 nauplii $\mathrm{f}^{-1} \mathrm{~d}^{-1}$ on day 6 , and 46 nauplii $\mathrm{f}^{-1} \mathrm{~d}^{-1}$ on day 4 in M8 and M2, respectively, and decreasing from day 10 and day 14 in M8 and M2, respectively. Naupliar recruitment showed another peak on day 10 in M8 (68 nauplii $\mathrm{f}^{-1}$ $\mathrm{d}^{-1}$ ), whereas a more constant but lower naupliar recruitment was observed in $\mathrm{M} 2$ from day 4 to day 14 ( $\sim 0$ nauplii $\mathrm{f}^{-1} \mathrm{~d}^{-1}$, Fig. $\left.3 \mathrm{c}\right)$. Although females produced, on average, the same daily number of nauplii during their individual life span (29.1 nauplii $\mathrm{f}^{-1} \mathrm{~d}^{-1}$ 15 and 23.4 nauplii $\mathrm{f}^{-1} \mathrm{~d}^{-1}$, respectively. Unpaired $t$-test, $\mathrm{t}_{56}=1.41, p>0.05$ ), significantly more nauplii were recruited per females in M8 compared to M2 during the peak of the phytoplankton bloom from day 5 to 13 (53.2 nauplii $\mathrm{f}^{-1} \mathrm{~d}^{-1}$ and 37.4 nauplii $\mathrm{f}^{-1} \mathrm{~d}^{-1}$, respectively. Unpaired t-test, $\left.\mathrm{t}_{16}=4.26, p<0.05\right)$.

\subsubsection{Faecal production and feeding}

20 Feeding activity, expressed in terms of faecal pellet production, was almost identical in both treatments (Fig. 3d). Even though values were slightly different on day 0 (19.8 pellets $f^{-1} d^{-1}$ in $M 8$ and 35.8 pellets $f^{-1} d^{-1}$ in $M 2$ ), probably reflecting the previous feeding history of the copepod female in situ, they increased steadily and reached the highest value of 154 pellets $\mathrm{f}^{-1} \mathrm{~d}^{-1}$ on day 10 in both mesocosms. A decreasing trend was then recorded afterwards in both mesocosms, reaching low values similar to those recorded at the beginning of the experiment (61 pellets $\mathrm{f}^{-1} \mathrm{~d}^{-1}$ in $\mathrm{M} 8$ and 53 pellets $\mathrm{f}^{-1} \mathrm{~d}^{-1}$ in M2). The two trends were not significantly different (paired t-test, $t_{20}=1.85$, $p>0.05$ ), as were not the daily number of pellets produced by each female during their

\section{BGD}

4, 3913-3936, 2007

\section{Copepod \\ reproduction during \\ PeECE III}

Y. Carotenuto et al.

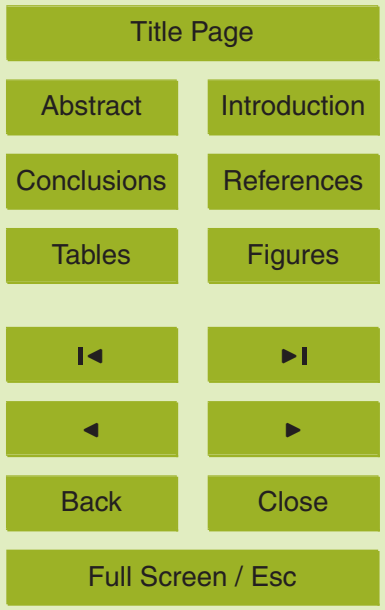

Printer-friendly Version

Interactive Discussion 
individual life span (76.7 pellets $\mathrm{f}^{-1} \mathrm{~d}^{-1}$ and 78.8 pellets $\mathrm{f}^{-1} \mathrm{~d}^{-1}$, respectively. Unpaired t-test, $\left.\mathrm{t}_{56}=0.25, p>0.05\right)$.

For some dates faecal pellet volume was also measured and converted in faecal volume production in order to estimate daily carbon ingestion rates using Eq. (1). Al5 though the carbon ingestion rates appeared to be slightly higher in M8 compared to M2 during the peak of the experiment (Fig. 3e), the carbon ingestion rates showed similar development over the experiment in both mesocosms (paired t-test, $t_{10}=0.20$, $p>0.05)$. In particular, ingestion rates were low on day $0\left(<35 \mu \mathrm{gC}^{-1} \mathrm{~d}^{-1}\right)$ and from day 13 until the end of the experiment $\left(<69 \mu \mathrm{g} \mathrm{C} \mathrm{f}^{-1} \mathrm{~d}^{-1}\right)$, and high during the peak of the bloom, with the highest values recorded on day 9 in both mesocosms (276 $\mu \mathrm{g} \mathrm{C}$

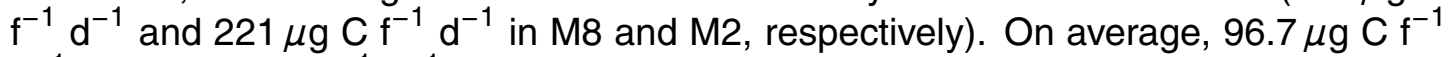
$\mathrm{d}^{-1}$ and $94.4 \mu \mathrm{g} \mathrm{C} \mathrm{f}^{-1} \mathrm{~d}^{-1}$ were ingested by copepods in $\mathrm{M} 8$ and in $\mathrm{M} 2$, respectively.

\subsubsection{Correlation analyses}

Egg production rates were strongly correlated to faecal pellet production and inges15 tion rates in both mesocosms (Tables 1 and 2). However, hatching success was neither correlated to egg production nor feeding activity. Thus, naupliar recruitment was strongly correlated to the egg production rate, but only to a lesser extent to hatching success (Tables 1 and 2). Further, copepod ingestion and egg production rates were significantly positively correlated to the total phytoplankton (Chla), diatoms and 20 prymnesiophyceae Chla equivalents, as well as cell numbers of Ehux and some of the nanoplankton in both mesocosms (Tables 1 and 2). In contrast, ingestion and egg production rates were either not significantly correlated, or negatively correlated to prasinophyceae and dinoflagellate $\mathrm{Chl}$ a equivalents and the smaller size fraction of the phytoplankton (picoplankton and cyanobacteria) in both mesocosms (Tables 1 and 2).

Hatching was not correlated to any algal group in the mesocosms, except for a slight inverse relationship with Chla and Prymensiophyceae Chla equivalents in M2 (Tables 1

BGD

4, 3913-3936, 2007

Copepod

reproduction during

PeECE III

Y. Carotenuto et al.

Title Page

Abstract

Introduction

Conclusions

Tables

References

Figures

14

- I

4

Back

Close

Full Screen / Esc

Printer-friendly Version

Interactive Discussion 
and 2). However, naupliar recruitment was positively correlated to Chl a in both mesocosms, but only in M8 naupliar recruitment showed significant positive correlations to the algal taxa developing during the bloom (diatoms, prymnesiophyceae and E. huxleyi) (Tables 1 and 2).

\section{Discussion}

The overall development of the phytoplankton bloom and copepod feeding and reproduction was similar in the two investigated mesocosms. This is in accordance with the reported development of most organisms in all the 9 mesocosms of the PeECE III experiment (Schulz et al., 2007 ${ }^{1}$ ). Although the total dissolved inorganic carbon (DIC) consumption of the plankton community increased with rising $\mathrm{CO}_{2}$ (Riebesell et al., in press), only a few calcifying organisms such as mollusc larvae (Schulz et al., $2007^{1}$; J. Nejstgaard, personal communication), virus types (Larsen et al., $2007^{2}$ ) and free-living bacteria (Allgaier et al., 2006) showed significant difference in abundance development between the $\mathrm{CO}_{2}$ treatments in the PeECE III study. Thus even as much as a threefold increase in $\mathrm{CO}_{2}$-concentration had only limited effects on the overall abundance of most of the components of the plankton in this experiment.

Previous mesocosms studies, however, showed $\mathrm{CO}_{2}$-related effects on growth, diversity and stoichiometry of the phytoplankton. During the PeECE I, lower growth and calcification of Ehux, as well as, lower PON:POP production ratio, were observed in the high $\mathrm{pCO}_{2}$ treatment $(700 \mu \mathrm{atm})$ (Engel et al., 2005). Also, differences in the phytoplankton composition during the next PeECE II were reported by Grossart et al. (2006), with Ehux and diatoms dominating the $2 \times$ present $\mathrm{CO}_{2}$ and almost no diatoms in the present $\mathrm{CO}_{2}$ treatment.

\footnotetext{
${ }^{2}$ Larsen, J. B., Larsen, A., Thyrhaug, R., Bratbak, G., and Sandaa, R.-A.: Marine viral populations at elevated nutrient and $\mathrm{pCO}_{2}$ levels, Biogeosciences Discuss., in preparation, 2007.
}

BGD

4, 3913-3936, 2007

\section{Copepod}

reproduction during

PeECE III

Y. Carotenuto et al.

Title Page

Abstract

Introduction

Conclusions

Tables

References

Figures

14

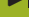

4

Back

Close

Full Screen / Esc

Printer-friendly Version

Interactive Discussion 
$\mathrm{CO}_{2}$-related effects on the phytoplankton were also observed in other field studies. Tortell et al. (2002) reported a shift in the taxonomic composition of an Equatorial Pacific phytoplankton assemblage exposed to future $\mathrm{pCO}_{2}$. In particular, Tortell and co-workers showed that though the total phytoplankton biomass and primary produc5 tivity did not differ between the treatments, diatoms dominated at high $\mathrm{CO}_{2}$ concentrations $(750 \mu \mathrm{atm})$, whereas Phaeocystis sp. dominated at low $\mathrm{CO}_{2}$ concentrations (150 $\mu \mathrm{atm})$. Similarly, a recent mesocosm study conducted near the Southern coast of Korea, showed that although the overall phytoplankton community remained unaffected at a $\mathrm{pCO}_{2}$ of $750 \mathrm{ppm}$ (as indicated by the POC accumulation), the diatom 10 Skeletonema costatum showed a $40 \%$ increase of the growth rate (Kim et al., 2006).

Concerning the effect on copepods, Kurihara et al. (2004) reported lower egg production, hatching success and abnormal larval morphology in the copepods Acartia steueri and $A$. erythraea. However, these experiments were carried out at a much higher $\mathrm{CO}_{2}$ concentration (10000 ppm) than used in any of the other studies, and its relevance for a future scenario is thus debatable.

We did not directly assess the effect of changed $\mathrm{pH}$ on copepod reproduction, because we did not keep the high $\mathrm{pCO}_{2}$ level in the water from the $3 \times \mathrm{CO}_{2}$ mesocosm during the incubations in the laboratory. However, it is unlikely that the potentially lowered $\mathrm{pH}$ in the $3 \times$ treatment would have any direct effect on the reproduction in any case. Because, laboratory studies have shown that egg production, hatching success and naupliar mortality were not affected when seawater $\mathrm{pH}$ was reduced by less than 1 unit (from 8.1 to 7.3) (Kurihara et al., 2004), while numerical simulations shows that the $\mathrm{pH}$ would drop only 0.7 units by the year 2300 if the atmospheric $\mathrm{CO}_{2}$ exceeds $1900 \mu \mathrm{atm}$ (Caldeira and Wickett, 2003), which is far beyond the $3 \times$ treatment here.

C. finmarchicus had similar feeding and egg production rates in the two $\mathrm{CO}_{2}$ treatments. However, the hatching success and naupliar recruitment was lower during the peak of the bloom in the $3 \times \mathrm{CO}_{2}$ mesocosm compared to the present $(1 \times) \mathrm{CO}_{2}$ treatment, despite that there was a higher food carbon concentration during that period. This may be explained by a combination of food saturation and/or lower qual-

\section{BGD}

4, 3913-3936, 2007

\section{Copepod \\ reproduction during PeECE III}

Y. Carotenuto et al.

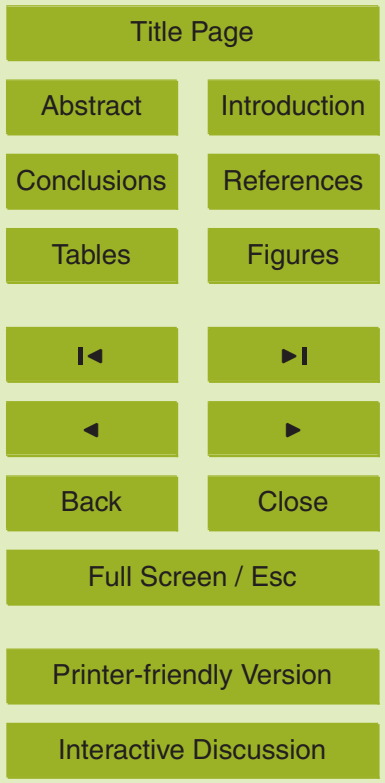

EGU 
ity/deleterious food composition in the $3 \times \mathrm{CO}_{2}$ treatment. Using an average $\mathrm{C}: \mathrm{Chl} a$ ratio of 40-50 (Båmstedt et al., 2000), we can extrapolate that about $400 \mu \mathrm{g}$ algae prey $\mathrm{C} \mathrm{I}^{-1}$ were already available for $C$. finmarchicus at the peak of the bloom in the $1 \times$ treatment. This value is above the food concentration needed to obtain a satura5 tion response in ingestion rates (Frost, 1972) and egg production (Poulet et al., 1996) reported for Calanus species, and thus the slightly higher $\mathrm{C}$ biomass developing at the peak of the bloom in $3 \times$ (maximum $630 \mu \mathrm{g} \mathrm{Cl}^{-1}$ ) did not improve the copepod egg production further. The less efficient recruitment supported by the algal assemblage in the $3 \times$, could be due to toxic metabolites impairing hatching success and naupliar 10 recruitment (Miralto et al., 1999, lanora et al., 2004), or algal prey nutritional deficiency in terms of $\mathrm{N}$ (Jones and Flynn, 2005), fatty acids (Jonasdottir and Kiørboe, 1996), or sterols (Klein-Breteler et al., 1999) content. Since we did not perform any detailed chemical analysis of the phytoplankton developing in the mesocosms, we cannot determine whether the algae developing in the $3 \times \mathrm{CO}_{2}$ treatment were more nutritionally 15 deficient or toxic compared to the algae in the $1 \times$ (present) $\mathrm{CO}_{2}$ level mesocosms. However, it is possible that the developing microzooplankton community have supported the reproduction at the end of the bloom, while the lower nauplii recruitment during the top of the bloom in the $3 \times$ mesocosm may be due to a high and unfavourable stoichiometric carbon to nitrogen $(\mathrm{C}: \mathrm{N})$ content in the plankton community.

During the PeECE III experiment, abundance of the whole microzooplankton community was assessed in the pre-bloom, bloom peak, decline and termination periods. According to these data, the build up of the entire community, characterized by heterotrophic dinoflagellates, ciliates and heterotrophic microflagellates, started in the bloom phase and reached the maximum when the phytoplankton bloom was declining (Suffrian et al., 2007 ${ }^{3}$ ). Since Calanus have been shown to feed selectively on microzooplankton in similar previous experiments (Nejstgaard et al., 2001b), and mi-

\footnotetext{
${ }^{3}$ Suffrian, K., Simonelli, P., Antia, A. N., Putzeys, S., Carotenuto, Y., and Nejstgaard, J. C.: Microzooplankton grazing and phytoplankton growth in marine mesocosms with increased $\mathrm{CO}_{2}$ levels, Biogeosciences Discuss., in preparation, 2007.
}

BGD

4, 3913-3936, 2007

\section{Copepod \\ reproduction during \\ PeECE III}

Y. Carotenuto et al.

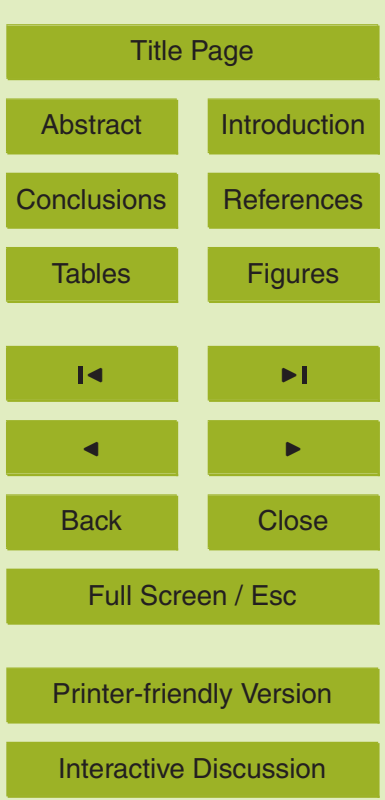

EGU 
crozooplankton may be a more nutritious food compared to feeding on phytoplankton alone (Tang and Taal, 2005; Veloza et al., 2006), the presence of these organisms, especially during the decline of the bloom, when the algal biomass was again under saturating levels, may have represented an additional valuable food source for cope5 pods (compare Ohman and Runge, 1994). This heterotrophic community may therefore both have sustained the copepod fecundity and the higher hatching success during the decline of the bloom in both mesocosms.

At $3 \times \mathrm{pCO}_{2}$ levels, the community consumed up to $39 \%$ more DIC compared to $1 \times$ levels, while inorganic nutrient uptake remained the same in all treatments (Riebesell 10 et al., 2007). Therefore, the stoichiometry of C:N drawdown increased from 6.0 at low $(1 \times) \mathrm{CO}_{2}$ to 8.0 at high $(3 \times) \mathrm{CO}_{2}$, thus exceeding the Redfield $\mathrm{C}: \mathrm{N}$ ratio of 6.6 in today's ocean. This excess carbon consumption in elevated $\mathrm{CO}_{2}$ concentrations could result in both a higher total prey $\mathrm{C}$ availability potentially boosting the overall $\mathrm{C}$ assimilation at higher trophic levels with potential increased growth and fat production

15 in copepods, while at the same time also resulting in a nutritionally suboptimal diet for egg hatching and nauplii development resulting in decreased recruitment success. However, whether slightly elevated $\mathrm{C}: \mathrm{N}$ ratios are negative for copepod reproduction success have been debated (Augustin and Boersma, 2006). This indicates that the net impact on copepods from increased future $\mathrm{CO}_{2}$ levels may be very complex. Thus one may speculate that the response of the zooplankton to elevated $\mathrm{CO}_{2}$ levels may vary depending on the (inorganic) nutritional level of the ecosystem. This could be tested in future manipulative experiment that takes into account the chemical composition of the phytoplankton too.

In conclusion, the higher algal biomass (dominated by diatoms, E. huxleyi, and 25 nanoplankton) developing during the peak of the bloom in the $3 \times \mathrm{CO}_{2}$ environment, may have been inferior food for $C$. finmarchicus hatching success and naupliar recruitment, compared to the prey field in the present $(1 \times) \mathrm{CO}_{2}$ environment. However, because only very limited $\mathrm{CO}_{2}$-related effects were observed on total standing stocks, taxonomic diversity and productivity of the primary producers when all replicates bags

\section{BGD}

4, 3913-3936, 2007

\section{Copepod \\ reproduction during \\ PeECE III}

Y. Carotenuto et al.

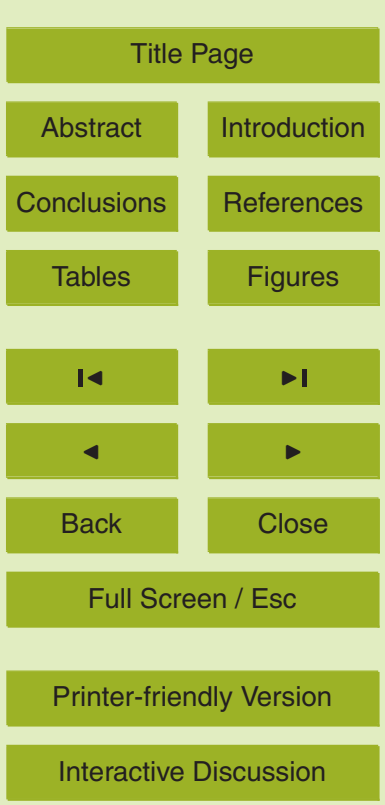

EGU 
were considered through out the entire PeECE III experiment (see other works in this volume), we cannot state that "increased $\mathrm{pCO}_{2}$ results in reduced copepod recruitment rates" for the entire period. Instead, the impact of climate change, in particular the raising of ocean surface $\mathrm{CO}_{2}$ concentration, on community structure and produc5 tivity in marine systems appears complex, and manipulative experiments conducted in large enclosed semi-natural systems still remain a useful tool for simultaneous monitoring of physical-chemical, biological and ecological responses to different scenarios of environmental change.

Acknowledgements. The authors thank the participants of the PeECE III project for their sup10 port during the experiment. The staff at the Marine Biological Station, University of Bergen, in particular Tomas Sørlie and Agnes Aadnesen, and the Bergen Marine Research infrastructure (RI) are gratefully acknowledged for support in mesocosm logistics. YC was funded by the European Marine Research Station Network (MARS) Travel Award for Young Scientist 2004. JCN was supported by the Norwegian Research Council (NRC) project 152714/120 30.

\section{References}

Allgaier, M., Riebsell, U., and Grossart, H. P.: Response of marine bacteria to $\mathrm{CO}_{2}$ enrichment in mesocosm perturbation studies, EGU General Assembly, Vienna, Austria, 2-7 April 2006, EGU06-A-08696, 2006.

Augustin, C. B. and Boersma, M.: Effects of nitrogen stressed algae on different Acartia species, J. Plankton Res., 28, 429-436, 2006.

Båmsted, U., Gifford, D. J., Irigoien, X., Atkinson, A., and Roman, M.: Feeding, in: ICES Zooplankton Methodology Manual, edited by: Harris, R. P., Wiebe, P. H., Lenz, J., Skjoldal, H. R., and Huntley, M., Academic Press, London, U. K., San Diego, USA., 297-399, 2000.

Barlow, R. G., Cummings, D. G., and Gibb, S. W.: Improved resolution of mono- and divinyl chlorophylls $a$ and $b$ and zeaxanthin and lutein in phytoplankton extracts using reverse phase C-8 HPLC, Mar. Ecol. Prog. Ser., 161, 303-307, 1997.

Caldeira, K. and Wickett, M. E.: Anthropogenic carbon and ocean pH, Nature, 425, 365, 2003.

Engel, A., Zondervan, I., Aerts, K., Beaufort, L., Benthien, A., Chou, L., Delille, B., Gattuso, J. P., Harlay, J., Heemann, C., Hoffmann, L., Jacquet, S., Nejstgaard, J., Pizay, M. D., Rochelle3928

\section{BGD}

4, 3913-3936, 2007

\section{Copepod \\ reproduction during \\ PeECE III}

Y. Carotenuto et al.

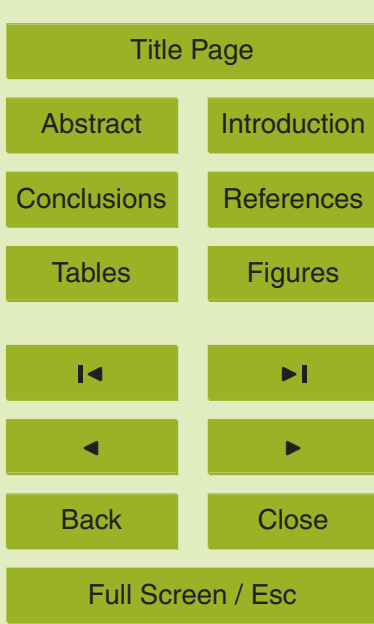

Printer-friendly Version

Interactive Discussion 
Newall, E., Schneider, U., Terbrueggen, A., and Riebesell, U.: Testing the direct effect of $\mathrm{CO}_{2}$ concentration on a bloom of the coccolithophorid Emiliania huxleyi in mesocosm experiments, Limnol. Oceanogr., 50, 493-507, 2005.

Frost, B. W.: Effects of size and concentration of food particles on the feeling bahavior of the marine planktonic copepod Calanus pacificus, Limnol. Oceanogr., 17, 805-815, 1972.

Grossart, H.-P., Allgaier, M., Passow, U., and Riebesell, U.: Testing the effect of $\mathrm{CO}_{2}$ concentration on the dynamics of marine heterotrophic bacterioplankton, Limnol. Oceanogr., 51, 1-11, 2006.

Houghton, J. T., Ding, Y., Griggs, D. J., Noguer, M., Van der Linden, P. J., Dai, X., Maskell, K., and Johnson, C. A. (Eds.): Climate Change 2001: The Scientific Basis. Contribution of Working Group I to the Third Assessment Report of the Intergovernmental Panel on Climate Change, Cambridge University Press, Cambridge, UK and New York, USA, 2001.

lanora, A., Miralto, A., Poulet, S. A., Carotenuto, Y., Buttino, I., Romano, G., Casotti, R., Pohnert, G., Wichard, T., Colucci-D'Amato, L., Terrazzano, G., and Smetacek, V.: Aldehyde suppression of copepod recruitment in blooms of a ubiquitous planktonic diatom, Nature, 429, 403-407, 2004.

Jansen, H. and Wolf-Gladrow, D. A.: Carbonate dissolution in copepod guts: a numerical model, Mar. Ecol. Prog. Ser., 221, 199-207, 2001.

Jonasdottir, S. H. and Kiørboe, T.: Copepod recruitment and food composition: Do diatoms affect hatching success?, Mar. Biol., 125, 743-750, 1996.

Jones, R. H. and Flynn, K. J.: Nutritional status and diet composition affect the value of diatoms as copepod prey, Science, 307, 1447-1459, 2005.

Kim, J.-M., Lee, K., Shin, K., Kang, J.-H., Lee, H.-W., Kim, M., Jang, P.-G., and Jang, M.-C.: The effect of seawater $\mathrm{CO}_{2}$ concentration on growth of a natural phytoplankton assemblage in a controlled mesocosm experiment, Limnol. Oceanogr., 51, 1629-1636, 2006.

Klein Breteler, W. C. M., Schogt, N., Baas, M., Schouten, S., and Kraay, G. W.: Trophic upgrading of food quality by protozoans enhancing copepod growth: role of essential lipids, Mar. Biol., 135, 191-198, 1999.

Kurihara, $\mathrm{H}$., Shimode, S., and Shirayama, Y.: Effects of raised $\mathrm{CO}_{2}$ concentration on the egg production rate and early development of two marine copepods (Acartia steuri and Acartia erythraea), Mar. Pollut. Bull., 49, 721-727, 2004.

Larsen, A., Castberg, T., Sandaa, R. A., Brussaard, C. P. D., Egge, J., Heldal, M., Paulino, A., Thyrhaug, R., van Hannen, E. J., and Bratbak, G.: Population dynamics and diversity

\section{BGD}

4, 3913-3936, 2007

\section{Copepod \\ reproduction during \\ PeECE III}

Y. Carotenuto et al.

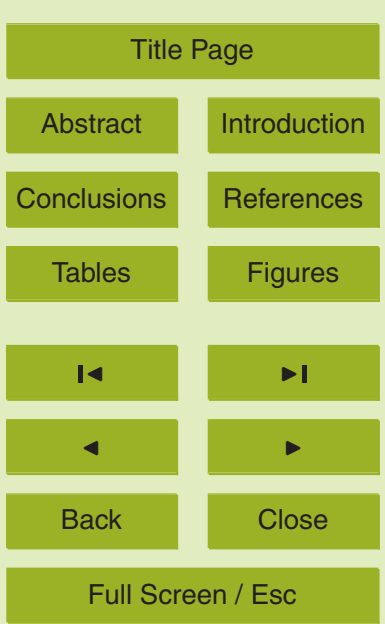

Printer-friendly Version

Interactive Discussion 
of phytoplankton, bacteria and viruses in a seawater enclosure, Mar. Ecol. Prog. Ser., 221, 47-57, 2001.

Mackey, M. D., Mackey, D. J., Higgins, H. W., and Wright, S. W.: CHEMTAX - a program for estimating class abundances from chemical markers: application to HPLC measurements of phytoplankton, Mar. Ecol. Prog. Ser., 144, 265-283, 1996.

Marie, D., Brussaard, C.P.D., Partensky, F., and Vaulot, D.: Enumeration of phytoplankton, bacteria, viruses in marine samples, in: Current Protocols in Cytometry, edited by: Robinson, J. P., Darzynkiewicz, Z., Dean, P. N., Orfao, A., et al., John Wiley \& Sons, Chichester, 11.11.111.11.15, 1999.

10 Miralto, A., Barone, G., Romano, G., Poulet, S. A., lanora, A., Russo, G. L., Buttino, I., Mazzarella, G., Laabir, M., Cabrini, M., and Giacobbe, M. G.: The insidious effect of diatoms on copepod reproduction, Nature, 402, 173-176, 1999.

Nejstgaard, J. C., Naustvoll, L. J., and Sazhin, A.: Correcting for underestimation of microzooplankton grazing in bottle incubation experiments with mesozooplankton, Mar. Ecol. Prog.

15 Ser., 221, 59-75, 2001a.

Nejstgaard, J. C., Hygum, B. H., Naustvoll, L. J., and Båmstedt, U.: Zooplankton growth, diet and reproductive success compared in simultaneous diatom- and flagellatemicrozooplankton-dominated plankton blooms, Mar. Ecol. Prog. Ser., 221, 77-91, 2001b.

Ohman, M. D. and Runge, J. A.: Sustained fecundity when phytoplankton resources are in short supply: omnivory by Calanus finmarchicus in the Gulf of St.Lawrence, Limnol. Oceanogr., 39, 21-36, 1994.

Poulet, S. A., Laabir, M., Chaudron, Y.: Characteristic features of zooplankton in the Bay of Biscay, Sci. Mar., 60, Supp. 2, 79-95, 1996.

Riebesell, U., Schulz, K. G., Bellerby, R. G. J., Botros, M., Fritsche, P., Meyerhöfer, M., Neill, C., Nondal, G., Oschlies, A., Wohlers, J., and Zöllner, E.: Enhanced biological carbon consumption in a high $\mathrm{CO}_{2}$ ocean, Nature, in press, 2007.

Rost, B., Riebesell, U., Burkhardt, S., and Sültemeyer, D.: Carbon acquisition of bloom-forming marine phytoplankton, Limnol. Oceanogr., 48, 55-67, 2003.

Tang, K. W. and Taal, M.: Trophic modification of food quality by heterotrophic protists: species30 specific effects on copepod egg production and egg hatching, J. Exp. Mar. Biol. Ecol., 318, 85-98, 2005.

Tortell, F. D., DiTullio, G. R., Sigman, D. M., and Morel, F. M. M.: $\mathrm{CO}_{2}$ effects on taxonomic composition and nutrient utilization in an Equatorial Pacific phytoplankton assemblage, Mar.

\section{BGD}

4, 3913-3936, 2007

Copepod

reproduction during

PeECE III

Y. Carotenuto et al.

Title Page

Abstract

Introduction

Conclusions

Tables

References

Figures

14

$>$ I

4

Back

Close

Full Screen / Esc

Printer-friendly Version

Interactive Discussion 
Ecol. Prog. Ser., 236, 37-43, 2002.

Veloza, A. J., Chu, F-L. E., and Tang, K. W.: Trophic modification of essential fatty acids by heterotrophic protists and its effects on the fatty acid composition of the copepod Acartia tonsa, Mar. Biol., 148, 779-788, 2006.

\section{BGD}

4, 3913-3936, 2007

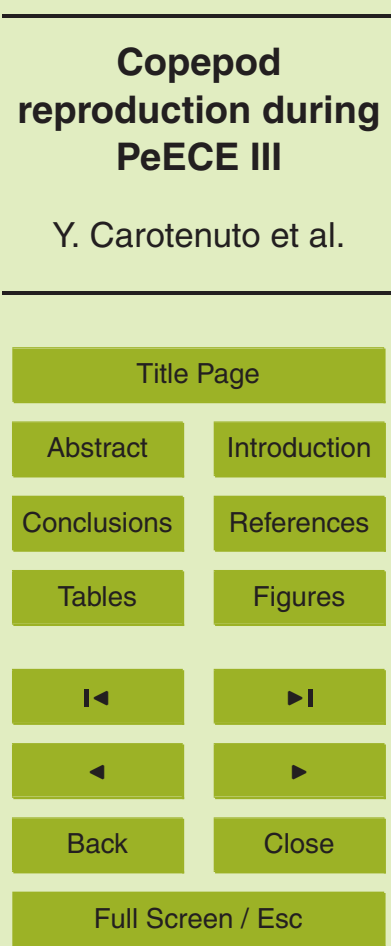

Printer-friendly Version

Interactive Discussion 
BGD

4, 3913-3936, 2007

\section{Copepod}

reproduction during

PeECE III

Table 1. Mesocosm $8\left(1 \times \mathrm{CO}_{2}\right.$ concentration) correlation analysis (Pearson) between copepod life history traits and phytoplankton concentration.

\begin{tabular}{|c|c|c|c|c|c|c|c|c|c|c|c|c|c|c|c|}
\hline & EPR & $\mathrm{HS}$ & NRR & PPR & IR & Chla & Diat & Prym & Prasi & Dino & Cyano & Ehux & Nano1 & Nano2 & Pico \\
\hline HS & $0.28 \mathrm{~ns}$ & - & & & & & & & & & & & & & \\
\hline NRR & $0.94^{\cdots}$ & $0.51^{* *}$ & - & & & & & & & & & & & & \\
\hline PPR & $0.92 \cdots$ & $0.34 \mathrm{~ns}$ & $0.88^{\cdots \cdots}$ & - & & & & & & & & & & & \\
\hline IR & $0.91^{\cdots}$ & $0.05 \mathrm{~ns}$ & $0.78^{*}$ & $0.93^{\cdots}$ & - & & & & & & & & & & \\
\hline Chl a & $0.91 \cdots$ & $-0.07 \mathrm{~ns}$ & $0.77^{\cdots \cdots}$ & $0.87^{\cdots}$ & $0.95 \cdots$ & _ & & & & & & & & & \\
\hline Diat & $0.74 *$ & $-0.12 \mathrm{~ns}$ & $0.60^{*}$ & $0.86 \cdots$ & $0.92 \ldots$ & $0.86 \cdots$ & - & & & & & & & & \\
\hline Prym & $0.90^{\cdots} \cdots$ & $-0.02 \mathrm{~ns}$ & $0.80^{\cdots \cdots}$ & $0.81^{\cdots \cdots}$ & $0.88^{*+}$ & $0.96 \cdots$ & $0.69^{*+}$ & - & & & & & & & \\
\hline Prasi & $0.37 \mathrm{~ns}$ & $-0.24 \mathrm{~ns}$ & $0.28 \mathrm{~ns}$ & $0.06 \mathrm{~ns}$ & $0.14 \mathrm{~ns}$ & $0.33 \mathrm{~ns}$ & $0.00 \mathrm{~ns}$ & $0.41 \mathrm{~ns}$ & - & & & & & & \\
\hline Dino & $-0.19 \mathrm{~ns}$ & $0.30 \mathrm{~ns}$ & $-0.24 n s$ & $-0.14 n s$ & $-0.17 \mathrm{~ns}$ & $-0.07 \mathrm{~ns}$ & $-0.11 n s$ & $-0.13 n s$ & $-0.23 \mathrm{~ns}$ & - & & & & & \\
\hline Cyano & $-0.52^{\circ}$ & $0.04 \mathrm{~ns}$ & -0.55 & $-0.63^{* *}$ & $-0.48 \mathrm{~ns}$ & $-0.43 \mathrm{~ns}$ & $-0.57^{\circ}$ & $-0.36 \mathrm{~ns}$ & $-0.11 \mathrm{~ns}$ & $0.65 *$ & - & & & & \\
\hline Ehux & $0.70^{*}$ & $0.13 \mathrm{~ns}$ & $0.66^{*}$ & $0.86^{\cdots *}$ & $0.72^{\circ}$ & $0.69^{\circ}$ & $0.80^{*+*}$ & $0.59^{\circ}$ & $-0.06 \mathrm{~ns}$ & $-0.38 \mathrm{~ns}$ & $-0.85 \cdots$ & _ & & & \\
\hline Nano1 & $0.57^{\circ}$ & $0.57^{\circ}$ & $0.66^{\circ}$ & $0.61^{*}$ & $0.50 \mathrm{~ns}$ & $0.43 \mathrm{~ns}$ & $0.32 \mathrm{~ns}$ & $0.50 \mathrm{~ns}$ & $-0.13 \mathrm{~ns}$ & $-0.24 \mathrm{~ns}$ & $-0.38 \mathrm{~ns}$ & $0.56^{\circ}$ & - & & \\
\hline Nano2 & $0.58^{\circ}$ & $0.27 \mathrm{~ns}$ & 0.65 * & $0.77^{\cdots \cdots}$ & $0.51 \mathrm{~ns}$ & $0.49 \mathrm{~ns}$ & $0.56^{\circ}$ & $0.45 \mathrm{~ns}$ & $-0.08 \mathrm{~ns}$ & $-0.47 \mathrm{~ns}$ & $-0.83 \cdots$ & $0.91 \cdots$ & $0.62^{*}$ & - & \\
\hline Pico & $-0.37 \mathrm{~ns}$ & $-0.46 \mathrm{~ns}$ & $-0.40 \mathrm{~ns}$ & $-0.45 \mathrm{~ns}$ & $-0.33 \mathrm{~ns}$ & $-0.28 \mathrm{~ns}$ & $-0.53 n s$ & $-0.10 \mathrm{~ns}$ & $0.60^{\circ}$ & $-0.45 \mathrm{~ns}$ & $0.07 \mathrm{~ns}$ & $-0.35 n s$ & $-0.67^{*}$ & $-0.30 \mathrm{~ns}$ & - \\
\hline Syn & $-0.74 \cdots$ & $-0.12 \mathrm{~ns}$ & $-0.75 \cdots$ & $-0.78^{* *}$ & $-0.68^{\circ}$ & $-0.87^{\cdots *}$ & $-0.79^{\circ}$ & $-0.82^{\cdots *}$ & $-0.40 \mathrm{~ns}$ & $0.45 \mathrm{~ns}$ & $0.91^{\cdots}$ & $-0.80 \cdots$ & $-0.37 \mathrm{~ns}$ & $-0.76^{\cdots}$ & $0.07 \mathrm{~ns}$ \\
\hline
\end{tabular}

Egg production rate (EPR), hatching success (HS), naupliar recruitment rate (NRR), pellet production rate (PPR) and ingestion rate (IR).

Chlorophylla (Chla), diatoms (Diat), Prymnesiophyceae (Prym), Prasinophyceae (Prasi), Dinoflagellates (Dino), Cyanobacteria (Cyano), Emiliania huxleyi (Ehux), nanoplankton 1 (Nano1), nanoplankton 2 (Nano2), picoplankton (Pico), Synechococcus (Syn).
Y. Carotenuto et al.

Title Page

Abstract

Introduction

Conclusions

References

Tables

Figures

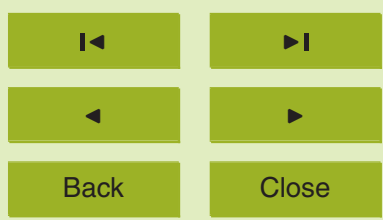

Full Screen / Esc

Printer-friendly Version

Interactive Discussion 
BGD

4, 3913-3936, 2007

\section{Copepod}

reproduction during

PeECE III copepod life history traits and phytoplankton concentration.

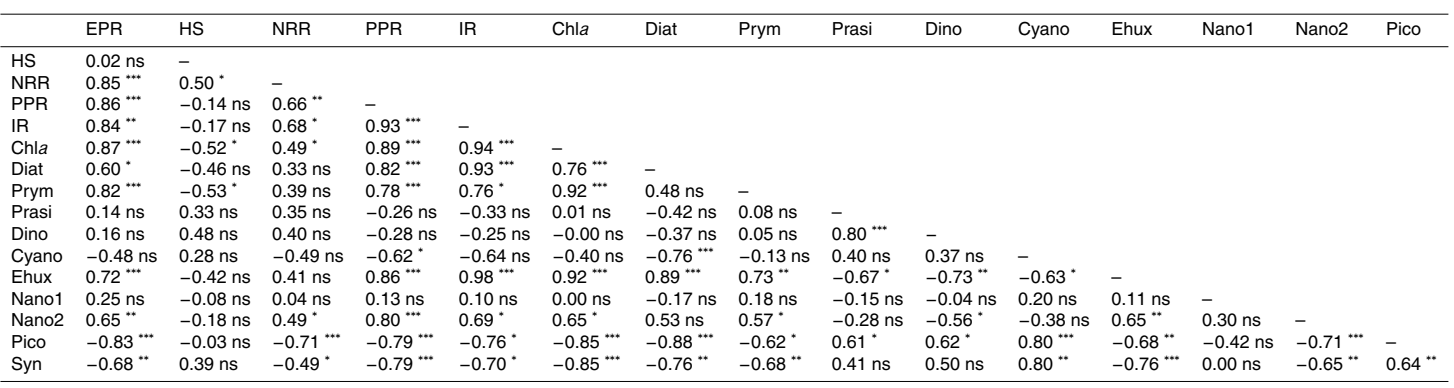

Egg production rate (EPR), hatching success (HS), naupliar recruitment rate (NRR), pellet production rate (PPR) and ingestion rate (IR).

Chlorophylla (Chla), diatoms (Diat), Prymnesiophyceae (Prym), Prasinophyceae (Prasi), Dinoflagellates (Dino), Cyanobacteria (Cyano), Emiliania huxleyi (Ehux), nanoplankton 1 (Nano1), nanoplankton 2 (Nano2), picoplankton (Pico), Synechococcus (Syn).

\section{Y. Carotenuto et al.}

Title Page

Abstract

Introduction

Conclusions

References

Tables

Figures

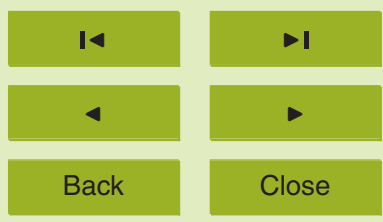

Full Screen / Esc

Printer-friendly Version

Interactive Discussion 

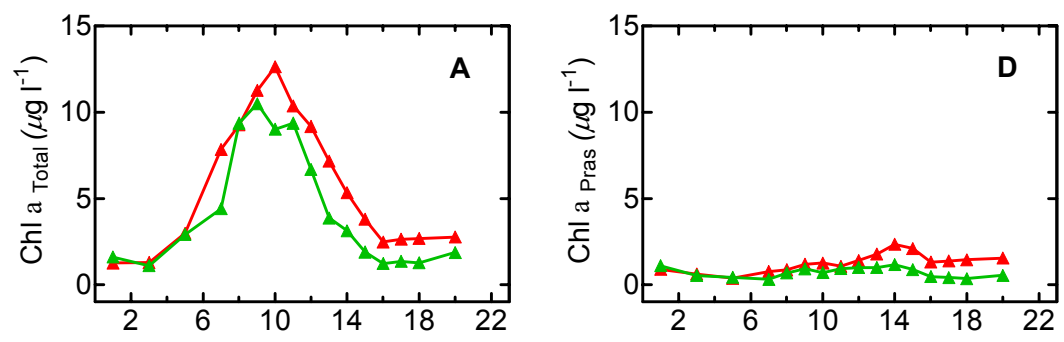

\section{BGD}

4, 3913-3936, 2007
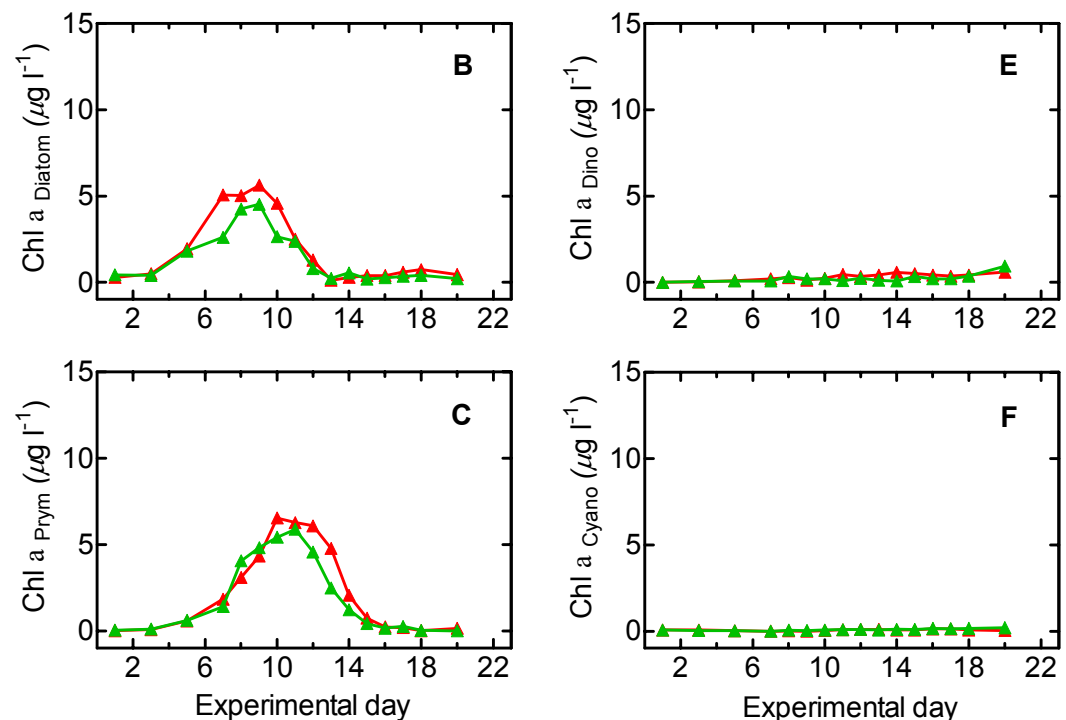

Title Page

Abstract

Introduction

Conclusions

References

Tables

Figures

14

I

4

Back

Close

\section{Full Screen / Esc}

Printer-friendly Version

Fig. 1. Temporal dynamics of Chlorophylla (Chla) concentrations in $1 \times$ present and $3 \times \mathrm{CO}_{2}$ mesocosms: Total Chla (A), Diatom (B), Prymnesiophyceae (C), Prasinophyceae (D), Dinoflagellates (E), and Cyanobacteria (F) associated Chla. Green colour $=1 \times \mathrm{CO}_{2}$ mesocosm (M8),

Interactive Discussion red colour $=3 \times \mathrm{CO}_{2}$ mesocosm (M2). 

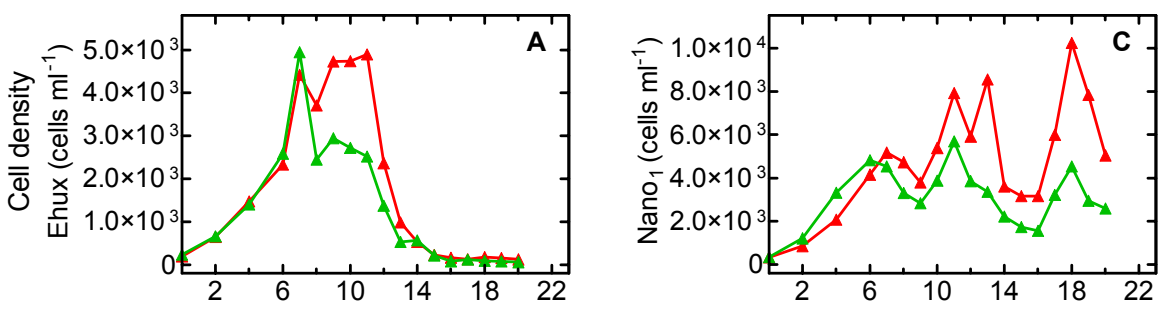

BGD

4, 3913-3936, 2007
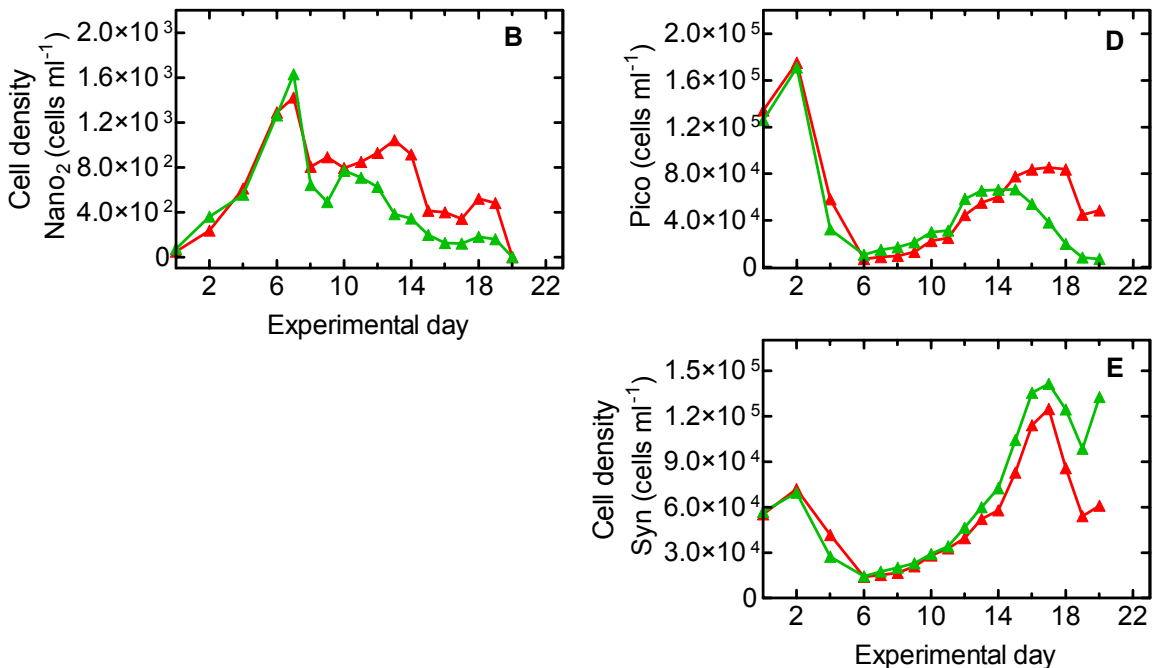

Title Page

Abstract

Introduction

Conclusions

References

Tables

Figures

I

-I

4

Back

Close

\section{Full Screen / Esc}

Fig. 2. Temporal dynamics of phytoplankton cell densities in $1 \times$ present and $3 \times \mathrm{CO}_{2}$ mesocosms: Emiliania huxleyi (A), nanoplankton1 (B), nanoplankton2 (C), picoplankton (D), and Synechococcus sp. (E). Colours as in Fig. 1. 

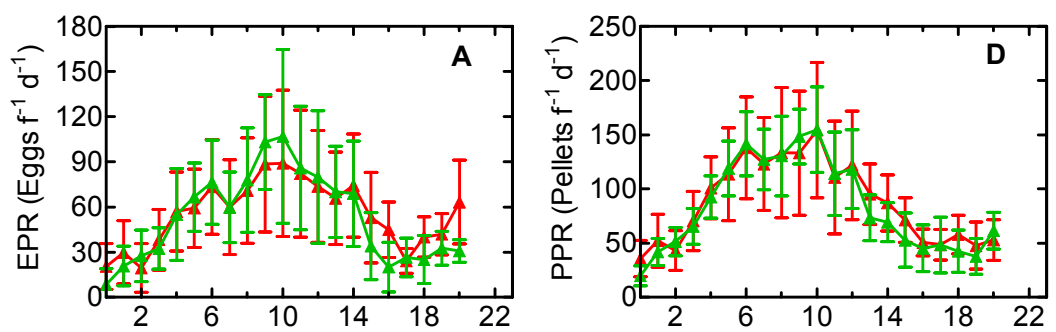

BGD
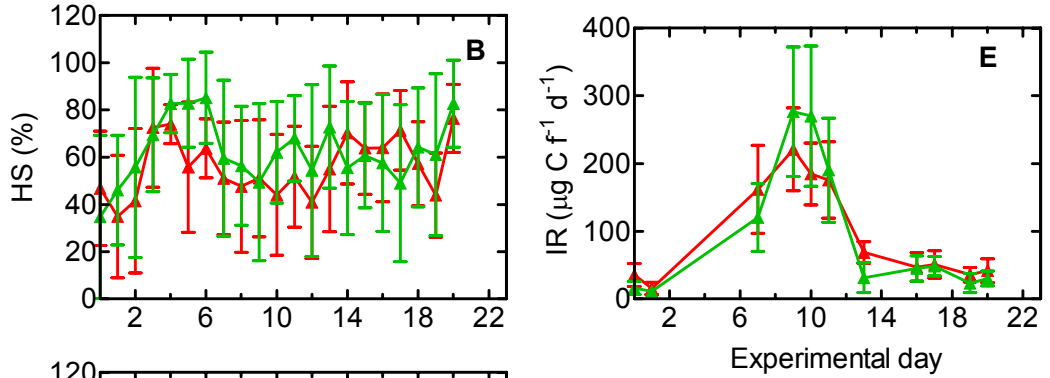

4, 3913-3936, 2007

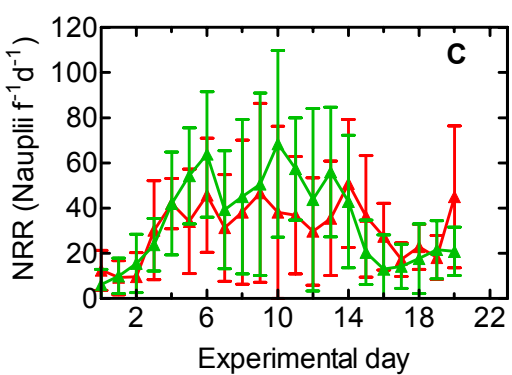

Copepod

reproduction during

PeECE III

Y. Carotenuto et al.

Title Page

Abstract

Introduction

Conclusions

References

Tables

Figures

I

$>$ I

4

Back

Close

\section{Full Screen / Esc}

Printer-friendly Version

Interactive Discussion

EGU 